\title{
Decreased Anxiety Level of MTs NW Perian Students Through Spiritual Therapy and Game Engineering Techniques
}

\author{
M. Deni Siregar ${ }^{1 *}$ dan Dukha Yunitasari²
}

\author{
${ }^{1,2}$ Hamzanwadi University \\ *Corresponding author. Email: *muhammaddenisiregar@gmail.com ${ }^{1}$
}

\begin{abstract}
Earthquake shocks that shook the island of Lombok with an $\mathrm{M}=7.0$ that occurred leaving very high anxiety for the victims. Hundreds of houses and important facilities were destroyed, at the epicenter. This incident makes every school child prefers not to go to school because of despair in seeing events that occur. Many complaints and sadness as if only they in this world who are victims. Anxiety level reduction activity was held for MTs NW Perian students who experienced things like the symptoms above, this triggered devotees to set a plan of what activities should be done when going to hold activities for MTs NW Perian students. The activities that will be carried out in this process are Opening, Fatihah and Sholawatunnahdlatain, Speeches by school principals and servants, Warming, Implementation of spiritual therapy and game play, relaxation, and closing which are held for 3 months. The desired goal in conducting trauma healing for MTs NW Perian students is to reduce the level of student anxiety, increase the low mentality of students in dealing with events, and improve students' mentality. Where the results do are Shiva who experience anxiety and severe stress experience increased memory and high awareness in dealing with problems that occur.
\end{abstract}

Keywords: Decreased levels of anxiety, spiritual, and game

\section{INTRODUCTION}

The earthquake in August 2018 shook the island of Lombok with a magnitude of 7.0 leaving trauma for victims who were worried about aftershocks. It also includes panic and anxiety, even resulting in stress due to loss of family and property. Thousands of houses and important facilities were destroyed, in the location of the epicenter. Natural disasters are one of the provisions of Allah S.W.T. which occurs in the universe (sunnatullah fi al-kaun) and is inseparable from the element of causality (causality) as one proof of His power. The commentators explain aspects of the causality of human sin and the occurrence of disasters and the correlation between human behavior with natural disasters. This article seeks to uncover the greatest natural catastrophe events in the history of mankind, especially during the times of the previous peoples, and the factors causing these disasters by analyzing the verses of the Qur'an related to the stories of previous peoples based on interpretations of the competent Mufassir scholars [1]. Lombok community, especially school children are very anxious and uneasy constantly so that it still tells a deep sadness. Apart from all that, students who are far from the epicenter have a very significant impact on the earthquake event. Where in a survey in one of the NW
Madrasah located in the village of Perian LombokTimur district experienced stress and trauma as well as very high anxiety among students and teachers. However, in this PKM, the servants try to reduce anxiety by using a game play on Shiva MTs NW Perian, where all students look very scared, do not want to go to class and do not want to sleep at home, still relying on campsites in the fields and terrain that impact on the low level of health and mentality of student life[2][3].

In general, anxiety is a psychological and physiological state characterized by somatic, emotional and behavioral components [4], [5] These components combine to create an uneasy feeling usually associated with anxiety, worry or fear. Anxiety is not always detrimental, because basically anxiety functions as a mechanism of self-control to stay alert to what will happen. However, if the level of anxiety is not controlled so that it has disrupted bodily activities, then it will obviously be very disturbing and can be detrimental. Anxiety in English is anxiety. In sports activities, anxiety is always present in a variety of things, including in every athlete. For example athletes feel afraid if they do not meet the expectations or demands of coaches, team managers, teammates, spectators and parties concerned. Anxiety as a state of stress without a clear cause and almost always accompanied by disorders of the 
autonomic nervous system and disorders of digestion. Anxiety as a mental strain that is usually accompanied by a disorder of the body that causes the individual concerned feel helpless and experience fatigue because they always have to be in circumstance alert to unclear threats. Therefore, as a creature of God who is endowed with reason, it should be our duty to uncover what is in the Qur'an as a scientific signal for the advancement of science [6], [7] In play, children make choices, solve problems, communicate, and negotiate. They create imaginary events, practice physical, social and cognitive skills. When playing children can express and train emotions from the experiences and events they encounter every day. Through playing together and taking on different roles, children develop the ability to see things from the perspective of others and engage in the behavior of leaders or followers - behaviors that they will need when socializing as adults. Spiritual therapy is a therapy carried out by demonstrating activities that are nuanced in the Islamic religion, such as focusing on the creator, praying in order to eliminate the anxiety felt.

\section{METHOD}

\section{Game plan}

Game play is a form of play that can be competed between several groups so that the stress that is felt disappears with laughter in game play [8], [9]. The game play is: a) Each group makes jargon names on the group, b) Each group makes yells, c) each group makes marches in groups, d) each group makes jargon, yell yel and mars and be sung together in the presence of other kempetitor, e) each group is instructed to carry out the mandate for carrying waste water, $f$ ) each group uses holaho to slide without opening handrails, g) each groups put nails in bottles, h) each group arranges the height and length of the group, i) each group draws, listens to music, listens to songs and so on.

\section{Spiritual Therapy}

Spiritual therapy is a term known to many people. However, the term can mean different things to each person.[10], [11]. After holding games for students it is recommended to rest and unwind for 8 minutes due to too many games being implemented. Then the next activity is conducting spiritual therapy where anxiety participants are given religious reinforcement by giving religious lectures covering the main causes of earthquakes, landslides, and tsunamis. All who hear the lecture become pensive and understand the meaning of all the deeds done.

\section{Relaxation}

Relaxation is an effort to relax, not only the physical body, but also our mind [12], [13]. But relaxation is not meditation. Relaxation is a step to meditation. This relaxation can be done with the aim to calm down, harmonize what is in the individual, and eliminate the burden, so that it is more relaxed and comfortable.[14] The relaxation activities undertaken are stretching the legs, hands and body in a clean room so that it feels light in the process of implementation. Then 5 minutes after relaxation, then the time to do inner relaxation, this is done by all participants closing their eyes, then focusing their thoughts and stones on Allah SWT.

Closing

Prayer is a form of appearing in a person in order to ask for what is desired by humans. Prayer also actually has essence as a means of communication. Namely communication between humans and their Lord which is very important in the arrival of the message and the fulfillment of a prayer [15], [16] . In closing, devotees pray together with all students and teachers, so that all doubts and motivations of all students return to normal as before the earthquake.

\section{RESULT AND DISCUSSION}

All of the above activities were carried out for 3 months from August to November 2018, where the results of the activities of reducing anxiety levels through spiritual therapy and game play were students who experienced severe anxiety and stress experienced increased memory and high awareness [17], [18]. in dealing with problems that occur, students are now beginning to be able to express all emotions and overflow to everyone in order to get the views of others, students begin to enter the classroom from floor 1 to floor 3 , students learn quietly with the teacher who gives lessons, students have high spirits and courage in carrying out teaching and learning activities, [19], [20] , students do their own relaxation at home and even invite their parents, students able to strengthen and motivate each other among students at school even in the community in men in case of problems, students are able to understand how to be aware of earthquake disasters by doing some rescue techniques, students are no longer worried because all of them believe that something good will get a good reward.

Handling the decrease in anxiety level which is done through spiritual and games makes the students no longer worried because all of them believe that something good will get a good reward, students always rely only on the Divine ; [19], [21], students do their own relaxation at home and even invite their parents, Students are able to strengthen and motivate each other among students at school even in the community in dealing with problems, Students are able to understand how to be aware of earthquake disasters by doing some techniques rescue, Students always do worship and keep closer to 
Allah SWT, Students often warm up muscles so that the anxiety they face disappears.

\section{CONCLUSION}

students do their own relaxation at home and even invite their parents, students able to strengthen and motivate each other among students at school even in the community in men in case of problems, students are able to understand how to be aware of earthquake disasters by doing some rescue techniques, students are no longer worried because all of them believe that something good will get a good reward.

\section{REFERENCES}

[1] S. Amir, "Scientific contemporary in al-Quran interpretation: An review for al-Sha'rawi method in Tafsir al-Sha'rawi," 2017.

[2] C. A. Severinsen, "Housing pathways of camping ground residents in New Zealand," Hous. Stud., vol. 28, no. 1, pp. 74-94, 2013.

[3] T. Robinson, "No right to rest: Police enforcement patterns and quality of life consequences of the criminalization of homelessness," Urban Aff. Rev., vol. 55, no. 1, pp. 41-73, 2019.

[4] N. Nazliati, R. Sari, and F. Fitriani, "Diagnosis Kecemasan Statistik Pendidikan Pada Mahasiswa Non-Matematika FTIK IAIN Langsa," J. Dedik. Pendidik., vol. 3, no. 1, pp. 61-75, 2019.

[5] A. U. Setyaningrum, "Hubungan Antara Efikasi Diri Akademik Dengan Kecemasan Berbicara Di Depan Umum Pada Mahasiswa Fakultas Psikologi Universitas Mercu Buana Yogyakarta." Universitas Mercu Buana Yogyakarta, 2018.

[6] C. Darmawan, "Musibah Di Era Modern Dalam Perspektif Pemikiran Quraish Shihab," Yonet. J. Manaj. Dakwah, vol. 1, no. 1, pp. 77-102, 2018.

[7] M. H. B. M. Johar, A. R. Bin Hamzah, and B. M. Nasir, "Menejemen Resiko Bencana Alam Berdasarkan Islam: Satu Kajian Pendahuluan," Wardah, vol. 20, no. 1, pp. 27-43, 2019.

[8] M. KHUSNA, "Pengaruh Penggunaan Gadget terhadap Minat Belajar dan Perilaku Peserta Didik Kelas VI MI Roudlotut Tholibin Banjarejo Rejotangan," 2019.

[9] N. P. P. Angela, "Strategi Event Digital Marketing Fiesta Black Tea dalam Membentuk Brand Image (Studi Kasus Program Bagi Bagi Diamond sebagai Minuman Gamers)." Universitas Bakrie, 2019.
[10] A. Hawi, "Remaja Pecandu Narkoba: Studi Tentang Rehabilitasi Integratif di Panti Rehabilitasi Narkoba Pondok Pesantren ArRahman Palembang," Tadrib, vol. 4, no. 1, pp. 99-119, 2018.

[11] H. A. Nata, Pembaruan pendidikan Islam di indonesia. Prenada Media, 2019.

[12] F. Aulia, "Art Therapy Bencana Sebagai Upaya Penanganan Trauma Anak Pasca Gempa Lombok," Sarwahita, vol. 16, no. 2, pp. 116$128,2019$.

[13] E. N. Hidayah, "Pengaruh relaksasi żikir terhadap penurunan kecemasan pada remaja korban broken home: studi kasus di Desa Tunahan Kec. Keling Kab. Jepara.” UIN Walisongo, 2019.

[14] S. Haryati, "Terapi Bermain 'Trauma Healing' Dengan Alat Permainan Edukatif (APE) Buatan Sendiri Pasca Gempa Pada Peserta Didik Kelompok TK A Paud Terpadu Putra Kaili Permata Bangsa," buku, 2019.

[15] U. A. Rahim, "Doa Sebagai Komunikasi Transedental Dalam Prespektif Komunikasi Islam," Idarotuna, vol. 2, no. 1, 2019.

[16] S. Yumnah and A. Khakim, "Konsep Dzikir Menurut Amin Syukur Dan Relevansinya Dengan Tujuan Pendidikan Islam," LISAN ALHAL J. Pengemb. Pemikir. dan Kebud., vol. 13, no. 1, pp. 97-118, 2019.

[17] S. Suyadi et al., "Pendidikan Inklusi dan Anak Berkebutuhan Khusus." Samudra Biru, 2019.

[18] T. Tenimar, "Penggunaan Strategi Teams Games Tournamen (TGT) Untuk Meningkatkan Hasil Belajar Ilmu Pengetahuan Alam (IPA) Siswa," J. Pendidik. Tambusai, vol. 3, no. 5, pp. 10731084, 2019.

[19] H. Nur Aditia, R. Wulandari, and E. Dewi Noorratri, "Pengaruh Spiritual Healing Terhadap Tingkat Kecemasan Pada Penderita HIV Kelompok Dukungan Sebaya Sukowati Di Kota Sragen." STIKES AISYIYAH SURAKARTA, 2019.

[20] N. Nurlaili, A. E. Nurdin, D. E. Putri, Y. Arif, B. Basmanelly, and F. Fernandes, "Pengaruh tehnik distraksi menghardik dengan spiritual terhadap halusinasi pasien," J. Keperawatan, vol. 11, no. 3, pp. 177-190, 2019.

[21] E. Rahmayati, R. N. Silaban, and S. Fatonah, "Pengaruh Dukungan Spritual terhadap Tingkat Kecemasan pada Pasien Pre-Operasi," $J$. Kesehat., vol. 9, no. 1, pp. 138-142, 2018. 